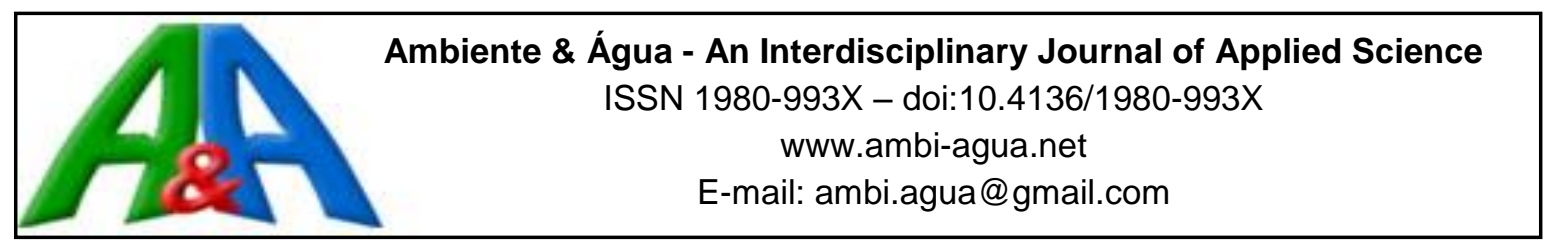

\title{
Use of agricultural and agroindustrial residues as alternative adsorbents of manganese and iron in aqueous solution
}

\author{
ARTICLES doi:10.4136/ambi-agua.2181
}

Received: 13 Sep. 2017; Accepted: 17 Jan. 2018

\section{Fernanda Lansa Furlan ${ }^{1}$; Nelson Consolin Filho ${ }^{2 *}$; Marcilene Ferrari Barriquello Consolin²; Morgana Suzsek Gonçalves ${ }^{3}$; Patrícia Valderrama ${ }^{2}$; Aziza Kamal Genena ${ }^{1}$}

\author{
${ }^{1}$ Universidade Tecnológica Federal do Paraná (UTFPR), Medianeira, PR, Brasil \\ Programa de Pós-Graduação em Tecnologia de Alimentos. E-mail: fernanda.furlan.lansa@gmail.com, \\ azizakg@utfpr.edu.br \\ ${ }^{2}$ Universidade Tecnológica Federal do Paraná (UTFPR), Campo Mourão, PR, Brasil \\ Departamento de Química. E-mail: consolin@utfpr.edu.br, marcilenef@utfpr.edu.br, patriciav@utfpr.edu.br \\ ${ }^{3}$ Universidade Tecnológica Federal do Paraná (UTFPR), Campo Mourão, PR, Brasil \\ Departamento de Engenharia Ambiental. E-mail: morgana@utfpr.edu.br \\ *Corresponding author
}

\begin{abstract}
The increase in the volume of agricultural and agroindustrial waste, associated with improper disposal, is a growing worldwide problem. The recovery of those residues is of crucial importance, since it reduces environmental impacts, protects public health, and allows the addition of value to the materials. One of the ways of exploiting adsorbents is related to the capacity of some wastes to be used as alternative adsorbents in the efficient removal of microcontaminants in aqueous systems. This work assessed the use of agricultural and agroindustrial residues: maize straw, wheat straw, soybean straw and soybean hulls for the production of alternative adsorbents to remove iron $(\mathrm{Fe})$ and manganese $(\mathrm{Mn})$ in water. For each residue investigated, two different polymers were obtained for use as adsorbents, a natural polymer (cellulose/lignin) and an EDTA-modified polymer (ethylenediaminetetraacetic acid). The adsorbents were characterized through FTIR (Fourier transform infrared spectroscopy) and nitrogen content. To evaluate the efficiency of the adsorbents, kinetic tests in batch mode and determination of Lagergren pseudo-first and pseudo-second order kinetic constants were performed. The results found that the modified polymer obtained from soybean hulls (SHE) showed increased Fe (96\%) and Mn (88\%) removal rate, in which the pseudo-second order kinetic model presented closer results between the experimental adsorption rates and the calculated ones for the two microcontaminants under study. In general, the modified soybean hulls proved to be a promising alternative adsorbent for the removal of iron and manganese in water treatment.
\end{abstract}

Keywords: adsorption, agribusiness, microcontaminants, waste recovery. 


\section{Uso de Resíduos Agrícolas e Agroindustriais como Adsorventes Alternativos de manganês e ferro em Sistema Aquoso}

\section{RESUMO}

O aumento do volume de resíduos agrícolas e agroindustriais gerados, acompanhados do descarte inadequado dos mesmos é um problema mundial crescente. $\mathrm{O}$ aproveitamento desses resíduos é de extrema importância, já que resulta na redução de impactos ambientais, preservação da saúde da população, e permite agregar valor à esses materiais. Uma das formas de aproveitamento está relacionada à capacidade de alguns resíduos serem utilizados como adsorventes alternativos na remoção eficiente de micro-contaminantes em sistemas aquosos. Este trabalho teve como objetivo investigar o uso dos resíduos agrícolas e agroindustriais: palha de milho, palha de trigo, palha de soja e casca de soja para produção de adsorventes alternativos para remoção de ferro $(\mathrm{Fe})$ e manganês $(\mathrm{Mn})$ em água. Para cada resíduo investigado, dois diferentes polímeros foram obtidos para uso como adsorventes, um polímero natural (celulose/lignina) e um polímero modificado com EDTA (ácido etilenodiaminotetraacético). Os adsorventes foram caracterizados por FTIR (espectroscopia de infravermelho por transformada de Fourier) e teor de nitrogênio. Para a avaliação da eficiência dos adsorventes foram realizados testes cinéticos, em regime batelada, e determinação das constantes cinéticas de pseudo-primeira e pseudo-segunda ordem de Lagergren. Os resultados obtidos indicaram que o polímero modificado obtido da casca de soja apresentou maior remoção de Fe $(96 \%)$ e Mn (88\%), em que o modelo cinético de pseudo-segunda ordem apresentou resultados mais aproximados entre os valores de quantidade adsorvida experimentais e os calculados para os dois micro-contaminantes em estudo. De modo geral, a casca de soja modificada mostrou ser um adsorvente alternativo promissor para a remoção de ferro e manganês no tratamento de águas.

Palavras-chave: adsorção, agroindústria, aproveitamento de resíduos, micro-contaminantes.

\section{INTRODUCTION}

Water is a basic necessity worldwide and is of immeasurable environmental importance since it is the primitive requirement for human life (Bushra et al., 2017, Carolin et al., 2017). Inorganic and organic chemicals are major life-threatening factors of water pollution (Sharma et al., 2017). Metal ion pollution is a most concerning topic of investigation in the present era due to its alarming rate of increase (Naushad et al., 2016). Domestic and industrial wastewaters containing metal ions are increasingly discharged into the environment and these metal ions are of significant importance as they are not biodegradable and cannot be metabolized by the environment but tend to accumulate in living organisms, causing various diseases and disorders (Hasanzadeh et al., 2017). Most of the metals are carcinogenic and/or pose severe health problems, such as organ damage, reduced growth and development, oxidative stress, and nervous system impairments (Naushad et al., 2015).

The presence of micro contaminant compounds in groundwater, and eventually in drinking water, is a serious environmental problem which poses a substantial risk to local resource users and to the natural environment (Adekola et al., 2016). For example, iron overload in animal models and humans increases oxidative stress and induces cardiomyopathy that may contribute to increased cardiovascular risk (Marques et al., 2015). Manganese (Mn) might be toxic at excess exposure. Elevated concentrations of $\mathrm{Mn}$ in drinking water were associated with impaired child development and indicated an adverse effect on birth length in pregnant women (Rahman et al., 2015). In order to get safe drinking water, excessive iron and manganese must be removed (Rangreez et al., 2017). 
The removal of toxic metals from water and wastewater has been achieved by several processes such as coagulation, electrochemical treatment, ion exchange, membrane separation, chemical precipitation and adsorption (Alqadami et al., 2016, Naushad et al., 2017, Reiad et al., 2012). In the last decade, the adsorption technique has been widely used for the removal of toxic metal from aqueous mediums (Ahamad et al., 2017) and has become one of the most preferred methods due to its high efficiency and low operational cost, making it a cost-effective method (Al-Othman et al., 2012). Furthermore, based on the regeneration, since adsorbents can be recreated by the desorption process, adsorption is also considered an environmentally acceptable method.

The selection of suitable precursors for the adsorption of metal ions from aqueous solutions is very important (Alqadami et al., 2017). The biosorption process using agricultural waste/plant material is an eco-friendly and easy method. Rapid industrialization associated with the population growth and intensive agricultural activities has prompted an increase in the amount and variety of agricultural and agroindustrial wastes produced (Asim et al., 2015). Most agricultural waste consists of three main structural components: lignin, cellulose and hemicellulose. These compounds possess adsorptive sites, such as ether, carbonyl, carboxyl, amine and hydroxyl groups, capable of absorbing metal species through ion exchange or complexation processes (Salleh et al., 2011).

Many agricultural wastes have directly or indirectly been used as sorbents for metal adsorption from water and wastewater which included rice husk, sunflower, potato, canola and walnut shell residues (Feizi and Jalili, 2015), peanut shell and orange peel (Surovka and Pertile, 2017).

In the light of the above, the present study investigated the use of agricultural and agroindustrial maize, soybean and wheat residues for producing alternative adsorbents, and their application in the removal of iron and manganese from aqueous solution.

\section{MATERIALS AND METHODS}

\subsection{Agricultural and Agroindustrial Waste}

Maize straw (MS), wheat straw (WT) and soybean straw (SS) soil residues were collected directly in the field after the harvest of the crops, respectively, in rural properties located in Campo Mourão, State of Paraná, Brazil and Peabiru, State of Paraná, Brazil, which use the notillage technique. Agroindustrial soybean hulls $(\mathrm{SH})$ residues were provided by the COAMO Agroindustrial Cooperativa warehouse located in the city of Araruna, PR, Brazil.

\subsection{Preparation of Adsorbents}

From each agricultural and agroindustrial residue, hemicelluloses were extracted to obtain a polymer composed of cellulose and lignin, known as a natural adsorbent of maize straw (MS), wheat straw (WT), soybean straw (SS) and soybean hull (SH). The stages of preparation and getting of e natural adsorbents followed the methodology described by Schafhauser et al. (2015).

For each residue, preparation of the adsorbent consisted of drying at $60^{\circ} \mathrm{C}$ in an oven for $24 \mathrm{~h}$, grinding with a cutting mill and screening (10 mesh).

Subsequently, for hemicellulose removal, $30 \mathrm{~g}$ of the sample were weighed on an analytical balance and the extraction was carried out following an eluotropic series of solvents (n-hexane/alcohol/water) in Soxhlet-type extractors with a hot plate. After extraction using each solvent of the series, the residues were dried in an oven at $60^{\circ} \mathrm{C}$ for $24 \mathrm{~h}$, weighed and returned to the Soxhlet system for further extraction with the other solvents. After extraction with water, 
the material was dried and weighed and the hemicellulose-free natural polymer composed of cellulose and lignin, i.e., the natural adsorbent, was obtained.

Part of this product (natural adsorbent) was put aside and the other part was modified with EDTA (ethylenediaminetetraacetic acid) to obtain a modified polymer called modified maize straw (MSE), wheat straw (WTE), soybean straw (SSE) and soybean hulls (SHE) adsorbent, obtained from the natural adsorbent.

The introduction of EDTA into the cellulose fibers of the adsorbents was carried out in a $50 \mathrm{~mL}$ round-bottomed flask fitted with a ball condenser. Each flask contained $5 \mathrm{~g}$ of natural adsorbent, $15 \mathrm{~g}$ of disodium salt EDTA and $210 \mathrm{~mL}$ of DMF (dimethylformamide). The mixture was stirred and heated on a magnetic stirrer with a heating plate at $75^{\circ} \mathrm{C}$ for $24 \mathrm{~h}$ and then vacuum-filtered on a sintered plate funnel with porosity of $40-60 \mu \mathrm{m}$. The material trapped on the filter was subjected to sequential washing with solvents and then dried at $75^{\circ} \mathrm{C}$ for $24 \mathrm{~h}$ on a drying oven until constant mass, in order to obtain EDTA-modified natural polymer (Pereira et al., 2010).

\subsection{Characterization of Adsorbents}

In order to characterize the adsorbents, they were weighed in an analytical balance, followed by a FTIR analysis (Fourier transform infrared spectroscopy) and total nitrogen determination.

For the FTIR analysis performed on a FTIR (IRAffinity-1S, Shimadzu) spectrometer, the pellets were prepared using $1 \mathrm{mg}$ of adsorbent and 100mg of spectroscopic grade $\mathrm{KBr}$. The spectra were collected over the 4000 to $400 \mathrm{~cm}^{-1}$ wavenumber range at a resolution of $4 \mathrm{~cm}^{-1}$ and 32 scans.

The determination of total nitrogen was carried out using the Kjeldahl method.

The analyses of the elements $\mathrm{C}, \mathrm{H}, \mathrm{N}$ and $\mathrm{O}$ for SHE and SS were carried using an elemental analyzer Eurovector EA 3000-S.

\subsection{Kinetic Study}

Kinetic tests of $\mathrm{Fe}$ or $\mathrm{Mn}$ adsorption in aqueous solution, in batch mode, were performed for each of adsorbent obtained. For each test, $20 \mathrm{~mL}$ of metal (Fe or $\mathrm{Mn}$ ) standard solution $\left(1 \mathrm{~g} . \mathrm{L}^{-1}\right), 1980 \mathrm{~mL}$ of distilled water and 3 drops of nitric acid were added to $4 \mathrm{~g}$ of adsorbent, resulting in a solution of $10 \mathrm{mg} . \mathrm{L}^{-1}$ for metal species and a concentration of $2 \mathrm{mg} \cdot \mathrm{mL}^{-1}$ of adsorbent material in solution. The solution was continuously stirred at $160 \mathrm{rpm}$, and kept at $25^{\circ} \mathrm{C}$ and $\mathrm{pH}$ of 6.8 . The adsorption time ranged from 0 to $180 \mathrm{~min}$, in which $20 \mathrm{~mL}$-aliquots were collected at predetermined intervals, followed by sample filtration in a sintered glass filter and the analysis of the Fe or Mn concentration through atomic absorption spectrophotometry, using an Analytik Jena NOVAA300 spectrophotometer.

The amount of $\mathrm{Fe}$ and $\mathrm{Mn}$ adsorbed (q), in $\mathrm{mg}^{-\mathrm{g}^{-1}}$, was calculated by Equation 1:

$\mathbf{q}=\frac{\left(\mathbf{C}_{0}-\mathbf{C}_{\mathrm{e}}\right) \mathbf{V}}{\mathbf{m}}$

in which $\mathrm{C}_{0}$ and $\mathrm{Ce}$ correspond to the initial concentration of the micro-contaminant and the equilibrium concentration $\left(\mathrm{mg} . \mathrm{L}^{-1}\right)$, respectively; $\mathrm{V}$ is the volume of solution $(\mathrm{L})$ and $\mathrm{m}$ is the amount of adsorbent used ( $\mathrm{g})$.

The adsorption efficiency of $\mathrm{Fe}$ and $\mathrm{Mn}$ from the aqueous solution was calculated by Equation 2:

$\%$ Adsorbed $=\frac{\mathrm{C}_{0}-\mathrm{C}_{\mathrm{e}}}{\mathrm{C}_{0}} \times 100$ 
The results of the kinetic tests were fitted to Lagergren pseudo-first and pseudo-second order kinetic models (Equation 3 and 4):

$$
\begin{aligned}
& \log \left(\mathbf{q}_{\mathrm{e}}-\mathbf{q}_{\mathbf{t}}\right)=\log \mathbf{q}_{\mathrm{e}}-\frac{\mathbf{k}_{1}}{2,303} \mathbf{t} \\
& \frac{\mathbf{t}}{\mathbf{q}_{\mathbf{t}}}=\frac{1}{\mathbf{k}_{2} \mathbf{q}_{\mathbf{e}}^{2}}+\frac{\mathbf{t}}{\mathbf{q}_{\mathrm{e}}}
\end{aligned}
$$

in which $\mathrm{q}_{\mathrm{e}}$ and $\mathrm{q}_{\mathrm{t}}$ are the adsorbed quantities $\left(\mathrm{mg}^{\mathrm{g}} \mathrm{g}^{-1}\right)$ at equilibrium and time $\mathrm{t}$, respectively; $\mathrm{k}_{1}$ is the pseudo-first order adsorption constant $\left(\mathrm{min}^{-1}\right)$ and $\mathrm{k}_{2}$ is the pseudo-second order adsorption constant $\left(\mathrm{g} \cdot \mathrm{mg}^{-1} \cdot \mathrm{min}^{-1}\right)$.

\section{RESULTS AND DISCUSSION}

\subsection{Collection of Adsorbents}

Table 1 shows the quantity and the respective percentage of extracts (hemicelluloses) removed in each extraction step using the eluotropic series of different solvents for each waste assessed.

Table 1. Waste weight before and after extractions using the eluotropic and total percentage rate of extractives

\begin{tabular}{|c|c|c|c|c|c|c|}
\hline \multirow{3}{*}{ Waste } & \multirow{3}{*}{$\begin{array}{c}\text { Initial weight } \\
\text { (g) }\end{array}$} & \multirow{2}{*}{\multicolumn{3}{|c|}{$\frac{\text { Weight after extraction }(\mathrm{g})}{\text { Extraction solvent }}$}} & \multirow{3}{*}{$\begin{array}{c}\text { Final weight } \\
\text { (g) }\end{array}$} & \multirow{3}{*}{$\begin{array}{l}\text { Percentage o } \\
\text { Removed } \\
\text { Extracts }(\%)\end{array}$} \\
\hline & & & & & & \\
\hline & & N-Hexane & Ethanol & Water & & \\
\hline MS & 30.00 & 28.35 & 25.75 & 20.95 & 9.05 & 30.17 \\
\hline WT & 30.00 & 28.00 & 26.15 & 21.00 & 9.00 & 30.00 \\
\hline SS & 30.00 & 28.13 & 25.74 & 20.35 & 9.65 & 32.17 \\
\hline SH & 30.00 & 26.00 & 24.10 & 19.25 & 10.75 & 35.83 \\
\hline
\end{tabular}
removed.

The process of removing extractives from the adsorbent material is an extremely important step when one aims at performing adsorption in aqueous solution, since hemicellulose, which is the most soluble constituent among lignocellulosic biomass materials, must be completely removed from the medium in order to prevent its solubilization and, consequently, the complexation of microcontaminants and the impairment of the final adsorption result. This process also avoids fungal and bacterial attack, increasing the useful life of adsorbent materials.

At the end of the process, all agricultural byproducts showed a reduction in total weight, demonstrating their efficiency in the extraction process. The biggest extraction occurred with SS $(35.83 \%)$.

Similar results were reported by Schafhauser et al. (2015) in extractions using the same solvents, in the same order, in maize straw. The authors observed that, at the end of the process, the total percentage of extractives removed was $30.15 \%$.

In order to obtain modified adsorbents, part of the natural adsorbents (MS, WT, SS, SH) were subjected to chemical modification with EDTA, followed by filtration, washing and drying. After those steps, the weight gain of modified adsorbents (MSE, WTE, SSE, SHE) was assessed to verify the EDTA's inclusion in the adsorbent materials: $10.75 \%$ for MSE, $11.00 \%$ for WTE, $8.80 \%$ for SSE and $33.00 \%$ for SHE.

Weight gain was observed in the four types of adsorbent materials after modifications with EDTA, confirming the introduction of this chelating agent into the structures of the lignocellulosic fibers forming straws and hulls. 
EDTA is a biodegradable and active agent containing two anhydride groups per molecule that can be used to introduce chelating abilities to the lignocellulosic materials through esterification reaction. This reaction allows introducing carboxylic and amine functional groups that present high ability to form stable complexes with heavy metal ions (Pereira et al., 2010). Therefore, the weight gain observed in modified adsorbent materials confirms that the carboxylate functions have been released and the amine functions have been conveyed into them.

\subsection{Fourier Transform Infrared Spectroscopy}

IR spectra for natural and modified adsorbents obtained are shown in Figures 1 (a) and (b), respectively. A comparison between the spectra revealed an increase and the appearance of strong bands in EDTA-modified straws and hulls at 1743-1747 $\mathrm{cm}^{-1}$, which can be attributed to the axial deformation $\mathrm{C}=\mathrm{O}$ of ester, at $1633 \mathrm{~cm}^{-1}$ due to the asymmetric axial deformation of the carboxylate, and at $1402-1408 \mathrm{~cm}^{-1}$ due to the symmetrical axial deformation of the carboxylate. This finding evidences the incorporation of two types of carbonyls, ester and carboxylate, and also confirms the introduction of EDTA into the modified adsorbents.

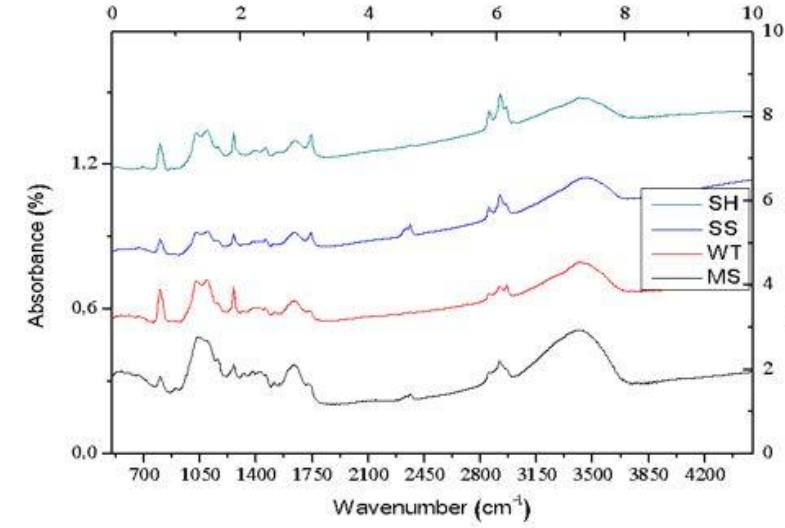

(a)

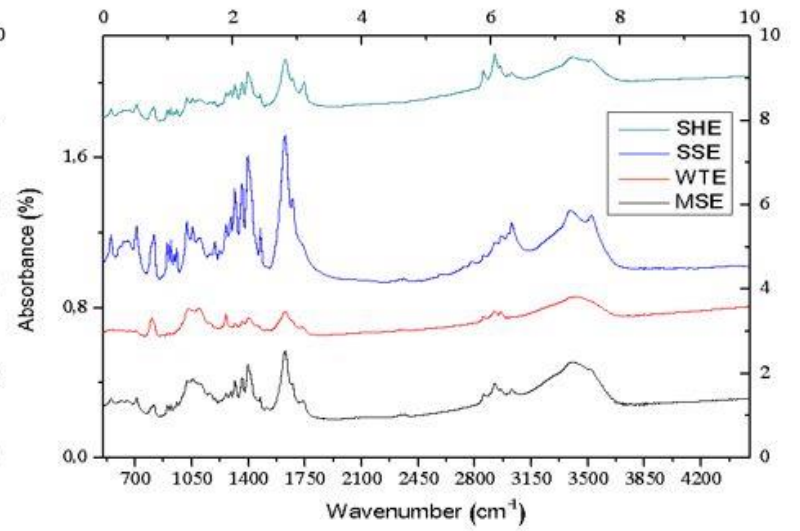

(b)

Figure 1. IR spectra for natural adsorbents (SH, SS, WT and MS) and modified adsorbents (SHE, SSE, WTE and MSE).

The results obtained in the present study are consistent with those reported by Pereira et al. (2010), who characterized through FTIR wood sawdust, EDTA-modified wood sawdust (SE), sugarcane bagasse (B) and EDTA-modified sugarcane bagasse (BE). When comparing the spectra of the modified materials with those of the starting materials, they observed the appearance of strong bands at $1742 \mathrm{~cm}^{-1}$ for $\mathrm{SE}$ and at $1741 \mathrm{~cm}^{-1}$ for BE, which correspond to stretching ester vibration. They also observed the presence of strong bands at $1634 \mathrm{~cm}^{-1}$, $1596 \mathrm{~cm}^{-1}$ and $1403 \mathrm{~cm}^{-1}$ for SE and at $1633 \mathrm{~cm}^{-1}, 1602 \mathrm{~cm}^{-1}$ and $1406 \mathrm{~cm}^{-1}$ for BE, related to asymmetric and symmetrical stretch of the carboxylate ion, respectively. These bands indicate that EDTA was introduced via ester linkages accompanied by a release of carboxylic functional groups.

Gusmão et al. (2013) studied the adsorption of methylene blue (MB) and gentian violet $(\mathrm{GV})$ in aqueous solution with unmodified sugarcane bagasse (B) and sugarcane bagasse modified with EDTA dianhydride (EB). When comparing the infrared spectra of EB with the unmodified bagasse spectrum, they observed the appearance of strong bands at $1741 \mathrm{~cm}^{-1}$, which can be attributed to the axial deformation of the ester bond $(-\mathrm{O}-\mathrm{C}=\mathrm{O})$, and bands at 1633 and $1406 \mathrm{~cm}^{-1}$, which are probably due to axially asymmetric and symmetrical deformations of carboxylate $\left(-\mathrm{COO}^{-}\right)$. These bands confirmed the introduction of EDTA 
dianhydride through the formation of ester bonds with the subsequent release of carboxylate functions.

\subsection{Determination of Total Nitrogen}

Data related to nitrogen analysis are presented in Table 2. A considerable increase in the nitrogen content after chemical modification with EDTA is observed. This finding also helps to confirm the introduction of EDTA in the materials through the incorporation of nitrogen in the modified adsorbents (WTE, MSE, SSE and SHE).

Table 2. Nitrogen content (\%) of natural and modified adsorbents.

\begin{tabular}{cc}
\hline Adsorbents & Nitrogen $(\%)$ \\
\hline WT & 0.16 \\
WTE & 0.87 \\
SS & 0.16 \\
SSE & 2.46 \\
MS & 0.07 \\
MSE & 0.78 \\
SH & 1.36 \\
SHE & 3.75 \\
\hline
\end{tabular}

Similar results were reported by Pereira et al. (2010) and Gusmão et al. (2013) with dianhydride of EDTA (EDTAD) modifications in sugarcane bagasse in the adsorption processes in aqueous solution. Both researchers verified that the nitrogen rate of sugarcane bagasse before EDTAD modification was $0.13 \%$ and after modification was $2.32 \%$. They explain that this fact occurred due to the incorporation of amine functions in the bagasse after esterification of hydroxyl, proving the introduction of EDTAD into it.

\subsection{Kinetics of Fe and Mn Adsorption}

The kinetic curve of manganese (Figure $2 \mathrm{a}$ and $2 \mathrm{~b}$ ) showed that the optimum adsorption time was approximately $15 \mathrm{~min}$ for SHE and $60 \mathrm{~min}$ for WT, SS, SH, MSE, WTE and SSE. In relation to the natural adsorbent of maize straw (MS), equilibrium was not reached up to 180 $\min$.

Overall, natural adsorbents showed reduced efficiency in the removal of manganese (Figure 2a). The maximum adsorbed amount was 16\% for MS, 19\% for WT, 13\% for SS and $6 \%$ for $\mathrm{SH}$.

Among modified adsorbents, the amounts of manganese removed were higher than that observed with natural adsorbents, except for the MSE, which showed a removal rate below 5\%. The maximum removal was achieved using the modified soybean hulls adsorbent (SHE), with $88 \%$.

Tavlieva et al. (2015) used rice husk ash to remove Mn ions in aqueous solutions. The results showed that the Mn removal rate was $26.62 \%$, much lower than that obtained in the present study with modified soybean hulls (SHH).

Regarding the kinetic tests for iron removal with the natural adsorbents, the kinetic curve (Figure 2c) shows that the optimum adsorption time was approximately $30 \mathrm{~min}$ for MS and WT, $60 \mathrm{~min}$ for SS and $180 \mathrm{~min}$ for SH. The maximum iron removal level achieved with natural adsorbents was $78 \%$, using soybean hulls $(\mathrm{SH})$. 


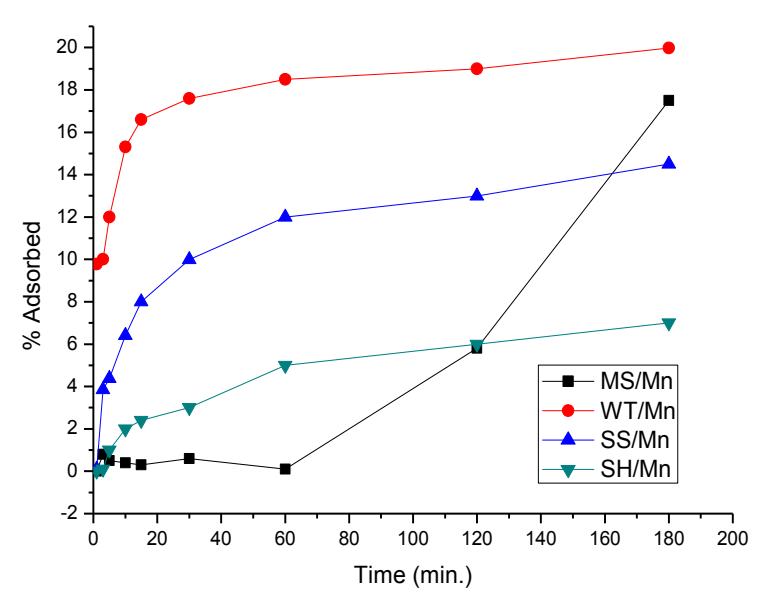

(a)

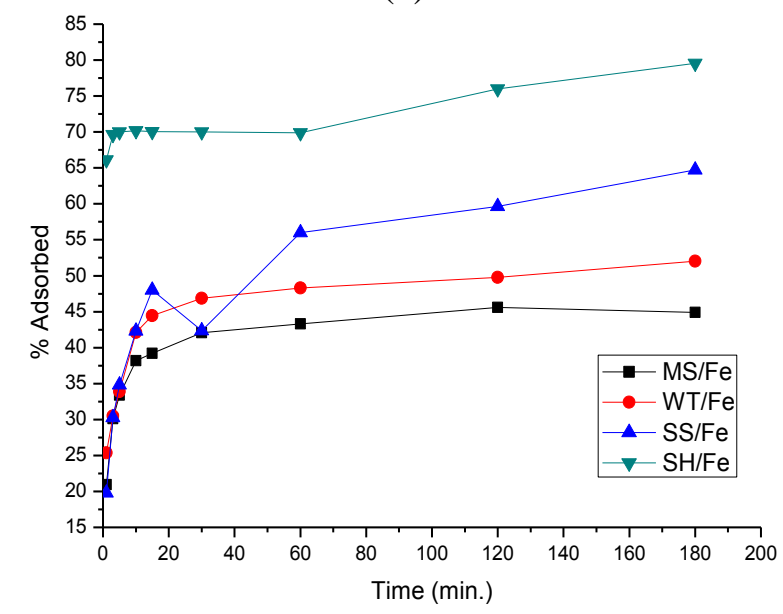

(c)

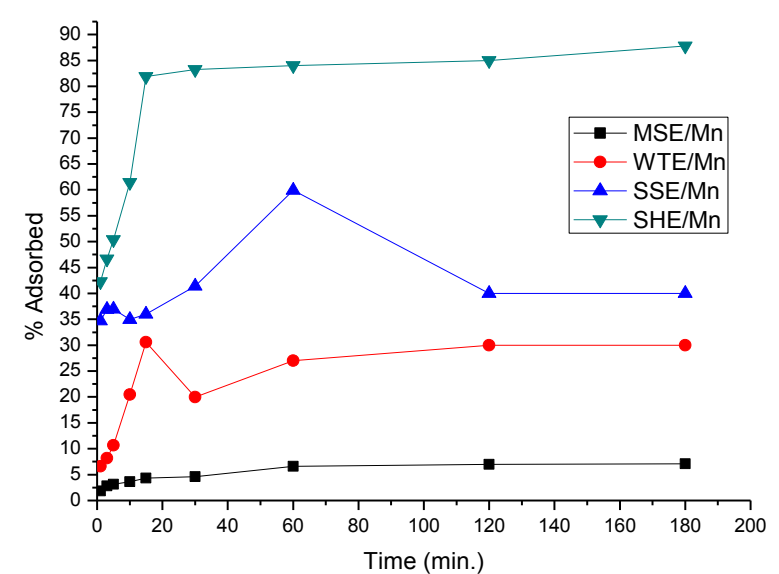

(b)

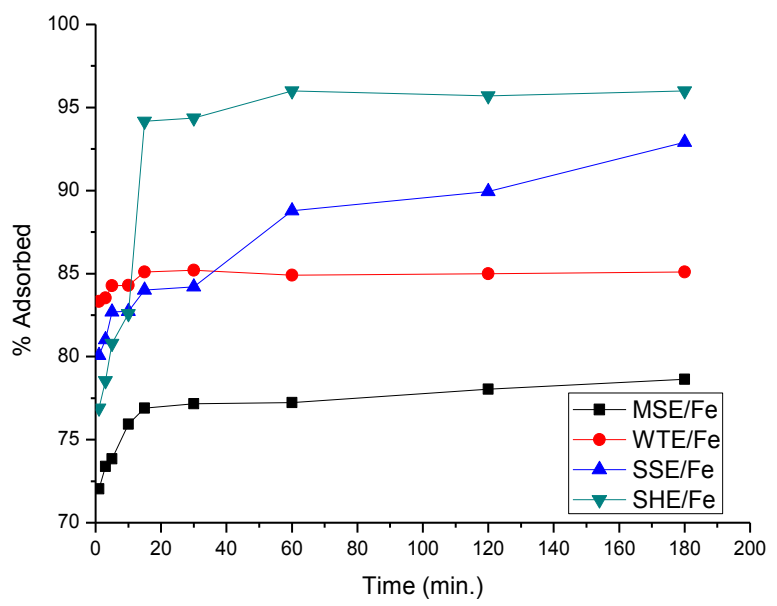

(d)

Figure 2. Adsorption kinetics of manganese and iron by the following materials (a) MS, WT, SS and SH and (b) MSE, WTE, SSE and SHE.

Tavlieva et al. (2015) used rice husk ash to remove Mn ions in aqueous solutions. The results showed that the Mn removal rate was $26.62 \%$, much lower than that obtained in the present study with modified soybean hulls (SHH).

Regarding the kinetic tests for iron removal with the natural adsorbents, the kinetic curve (Figure 2c) shows that the optimum adsorption time was approximately $30 \mathrm{~min}$ for MS and WT, $60 \mathrm{~min}$ for SS and $180 \mathrm{~min}$ for SH. The maximum iron removal level achieved with natural adsorbents was $78 \%$, using soybean hulls ( $\mathrm{SH})$.

The adsorption of Fe with modified adsorbents (Figure 2d) revealed that the time required for the system to balance is approximately $15 \mathrm{~min}$ for MSE, WTE and SHE. There was no equilibrium for SSE up to 180 min.

It was also observed that the modified adsorption systems were more efficient in the removal of iron in comparison with the natural ones, reaching values $77 \%$ for MSE, $93 \%$ for SSE, $85 \%$ for WTE and $96 \%$ for SHE.

Considering only the modified soybean adsorbent (SHE), which showed the best results in $\mathrm{Fe}$ and $\mathrm{Mn}$ adsorption, the pseudo-second order kinetic model evidenced results that more closely match the experimental and calculated $\mathrm{q}_{\mathrm{e}}$ values (Table 3), with higher coefficients of determination $\left(\mathrm{R}^{2}\right)$ in comparison with the pseudo-first order kinetic model, describing better the adsorption process. 
According to Feng et al. (2011), the pseudo-second order model assumes that the velocitylimiting factor may be the chemical adsorption involving valence forces, through the sharing or exchange of electrons between heavy metal ions and the adsorbent. It is a model that describes well the processes of chemical adsorption that involve donation or exchange of electrons between the adsorbate and the adsorbent, as covalent forces and ionic exchanges (Ho and Mckay, 2000).

Table 3. Parameters of the pseudo-first order and pseudo-second order kinetic models for $\mathrm{Mn}$ and Fe adsorption in SHE.

\begin{tabular}{|c|c|c|c|c|c|c|c|}
\hline \multirow[b]{2}{*}{ Metal } & \multirow{2}{*}{$\begin{array}{l}\text { qe (exp) } \\
\left(\mathrm{mg} \mathrm{g}^{-1}\right)\end{array}$} & \multicolumn{3}{|c|}{ Pseudo-first order } & \multicolumn{3}{|c|}{ Pseudo-second order } \\
\hline & & $\begin{array}{l}\text { qe (calc) } \\
\left(\mathrm{mg} \cdot \mathrm{g}^{-1}\right)\end{array}$ & $\begin{array}{c}\mathbf{k}_{1} \\
\left(\mathbf{m i n}^{-1}\right)\end{array}$ & $\mathbf{R}^{2}$ & $\begin{array}{l}\text { qe (calc) } \\
\left(\mathrm{mg}^{-1} \mathrm{~g}^{-1}\right)\end{array}$ & $\begin{array}{c}\mathbf{k}_{2} \\
\left(\mathrm{~g} \cdot \mathrm{mg}^{-1} \cdot \mathrm{min}^{-1}\right)\end{array}$ & $\mathbf{R}^{2}$ \\
\hline Mn & 1.00 & 0.41 & 0.021 & 0.735 & 1.00 & 0.359 & 0.999 \\
\hline $\mathbf{F e}$ & 2.60 & 0.95 & 0.021 & 0.701 & 2.59 & 0.168 & 0.999 \\
\hline
\end{tabular}

In the present study, the pseudo-second order adsorption rate $\left(\mathrm{k}_{2}\right)$ for $\mathrm{Mn}$ and $\mathrm{Fe}$ in SHE was 0.359 and $0.168 \mathrm{~g} \cdot \mathrm{mg}^{-1} \cdot \mathrm{min}^{-1}$, respectively.

\section{CONCLUSION}

Agricultural and agroindustrial wastes are high-abundance and low-cost materials that can be used as alternative adsorbents for the removal of microcontaminants in water treatment systems.

All the adsorbents produced from maize, wheat and soybean residues were able to adsorb iron and manganese in aqueous solution. However, the soybean hulls modified adsorbent (SHE) showed the best results in the removal process, displaying an adsorption rate of $96 \%$ for iron and $88 \%$ for manganese. The pseudo-second order kinetic model presented a better description of the adsorption process of Fe and Mn in SHE adsorbent.

It is concluded that this material has proved promising for use in the adsorption of metal microcontaminants in aqueous solution, creating added value to waste and economic and environmental advantages.

\section{ACKNOWLEDGEMENTS}

We would like to thank Fundação Araucária for the financial support (scholarships and grants) from Agreement 043/2015, and Federal Technological University of Paraná (UTFPR), Campus Campo Mourão and Medianeira, for providing all structure and facilities.

\section{REFERENCES}

ADEKOLA, F. A.; HODONOU, D. S. S.; ADEGOKE, H. I. Thermodynamic and kinetic studies of biosorption of iron and manganese from aqueous medium using rice husk ash. Applied Water Science, v. 6, n. 4, p. 319-330, 2016. https://doi.org/10.1007/s13201014-0227-1

AHAMAD, T.; NAUSHAD, M.; AL-MASWARI, B. M.; AHMED, J.; ALOTHMAN, Z. A.; ALSHEHRI, S. M. et al. Synthesis of a recyclable mesoporous nanocomposite for efficient removal of toxic $\mathrm{Hg} 2+$ from aqueous medium. Journal of Industrial and $\begin{array}{lllllll}\text { Engineering Chemistry, } & \text { v. } & 53, & \text { p. } & \text { 268-275, }\end{array}$ http://dx.doi.org/10.1016/j.jiec.2017.04.035 
AL-OTHMAN, Z. A.; ALI, R.; NAUSHAD, M. Hexavalent chromium removal from aqueous medium by activated carbon prepared from peanut shell: Adsorption kinetics, equilibrium and thermodynamic studies. Chemical Engineering Journal, v. 184, p. 238-247, 2012. http://dx.doi.org/10.1016/j.cej.2012.01.048

ALQADAMI, A. A.; NAUSHAD, M.; ABDALlA, M. A.; AHAMAD, T.; ABDULlAH ALOTHMAN, Z. et al. Synthesis and characterization of Fe3O4 @TSC nanocomposite: highly efficient removal of toxic metal ions from aqueous medium. RSC Advances, v. 6, n. 27, p. 22679-22689, 2016.

ALQADAMI, A. A.; NAUSHAD, M.; ABDALLA, M. A.; AHAMAD, T.; ABDULLAH ALOTHMAN, Z. et al. Efficient removal of toxic metal ions from wastewater using a recyclable nanocomposite: A study of adsorption parameters and interaction mechanism. $\begin{array}{lllllll}\text { Journal of Cleaner Production, v. 156, p. 426-436, } 2017 . & \end{array}$ http://dx.doi.org/10.1016/j.jclepro.2017.04.085

ASIM, N.; EMDADI, Z.; MOHAMMAD, M.; YARMO, M. A.; SOPIAN, K. Agricultural solid wastes for green desiccant applications: an overview of research achievements, opportunities and perspectives. Journal of Cleaner Production, v. 91, p. 26-35, 2015. https://doi.org/10.1016/j.jclepro.2014.12.015

BUSHRA, R.; NAUSHAD, M.; SHARMA, G.; AZAM, A.; ALOTHMAN, Z. A. Synthesis of polyaniline based composite material and its analytical applications for the removal of highly toxic $\mathrm{Hg} 2+$ metal ion: Antibacterial activity against E. coli. Korean Journal of Chemical Engineering, v. 34, n. 7, p. 1970-1979, 2017. https://doi.org/10.1007/s11814017-0076-3

CAROLIN, C. F.; KUMAR, P. S.; SARAVANAN, A.; JOSHIBA, G. J.; NAUSHAD, M. Efficient techniques for the removal of toxic heavy metals from aquatic environment: A review. Journal of Environmental Chemical Engineering, v. 5, n. 3, p. 2782-2799, 2017. http://dx.doi.org/10.1016/j.jece.2017.05.029

FEIZI, M.; JALILI, M. Removal of heavy metals from aqueous solutions using sunflower, potato, canola and walnut shell residues. Journal of the Taiwan Institute of Chemical Engineers, v. 54, p. 125-136, 2015. https://doi.org/10.1016/j.jtice.2015.03.027

FENG, N.; GUO, X.; LIANG, S.; ZHU, Y.; LIU, J.; Biosorption of heavy metals from aqueous solutions by chemically modified orange peel. Journal of Hazardous Materials, v. 185, p. 49-54, 2011. https://doi.org/10.1016/j.jhazmat.2010.08.114

GUSMÃO, G. A. K.; GURGEL, A. V. L.; MELO, S. M. T.; GIL, F. L. Adsorption studies of methylene blue and gentian violet on sugarcane bagasse modified with EDTA dianhydride (EDTAD) in aqueous solutions: Kinetic and equilibrium aspects. Journal of Environmental Management, v. 118, p. 135-143, 2013. http://doi.org/10.1016/j.jenvman.2013.01.017

HASANZADEH, R.; MOGHADAM, P. N.; BAHRI-LALEH, N.; SILLANPÄÄ, M. Effective removal of toxic metal ions from aqueous solutions: 2- Bifunctional magnetic nanocomposite base on novel reactive PGMAMAn copolymer@Fe3O4 nanoparticles. Journal of Colloid and Interface Science, v. 490, p. 727-746, 2017. http://dx.doi.org/10.1016/j.jcis.2016.11.098

HO, Y. S.; MCKAY, G. The kinetics of sorption of divalent metal ions onto sphagnum moss peat. Water Research, v. 34, p. 735-742, 2000. https://doi.org/10.1016/S00431354(99)00232-8 
MARQUES, V. B.; NASCIMENTO, T. B.; RIBEIRO, R. F.; BROSEGHINI-FILHO, G. B.; ROSSI, E. M.; GRACELI, J. B. et al. Chronic iron overload in rats increases vascular reactivity by increasing oxidative stress and reducing nitric oxide bioavailability. Life Sciences, v. 143, p. 89-97, 2015. http://dx.doi.org/10.1016/j.lfs.2015.10.034

NAUSHAD, M.; AHAMAD, T.; AL-MASWARI, B. M.; ALQADAMI, A. A.; ALSHEHRI, S. M. Nickel ferrite bearing nitrogen-doped mesoporous carbon as efficient adsorbent for the removal of highly toxic metal ion from aqueous medium. Chemical Engineering Journal, v. 1330, p.1351-1360, 2017. http://dx.doi.org/10.1016/j.cej.2017.08.079

NAUSHAD, M.; AHAMAD, T.; SHARMA, G.; AL-MUHTASEB, A. H.; ALBADARIN, A. B.; ALAM, M. M. et al. Synthesis and characterization of a new starch/SnO2 nanocomposite for efficient adsorption of toxic $\mathrm{Hg} 2+$ metal ion. Chemical Engineering Journal, v. 300, p. 306-316, 2016. http://dx.doi.org/10.1016/j.cej.2016.04.084

NAUSHAD, M.; ALOTHMAN, Z.; SHARMA, G.; INAMUDDIN, G. Kinetics, isotherm and thermodynamic investigations for the adsorption of $\mathrm{Co}$ (II) ion onto crystal violet modified amberlite IR-120 resin. Ionics, v. 21, n. 5, p.1453-1459, 2015. http://doi.org/10.1007/s11581-014-1292-z

PEREIRA, V. F.; GURGEL, A. V. L.; GIL, F. L. Removal of Zn2+ from aqueous single metal solutions and electroplating wastewater with wood sawdust and sugarcane bagasse modified with EDTA dianhydride (EDTAD). Journal of Hazardous Materials, v. 176, p. 856-863, 2010. http://doi.org/10.1016/j.jhazmat.2009.11.115

RAHMAN, S. M.; KIPPLER, M.; AHMED, S.; PALM, B.; ARIFEEN, S. E.; VAHTER, M. Manganese exposure through drinking water during pregnancy and size at birth: A prospective cohort study. Reproductive Toxicology, v. 53, p. 68-74. 2015. https://doi.org/10.1016/j.reprotox.2015.03.008

RANGREEZ, T. A.; INAMUDDIN; ASIRI, A. M.; ALHOGBI, B. G.; NAUSHAD, M. Synthesis and Ion-Exchange Properties of Graphene Th(IV) Phosphate Composite Cation Exchanger: Its Applications in the Selective Separation of Lead Metal Ions. International Journal of Environmental Research and Public Health, v. 14, n. 7, p. 828, 2017. https://doi.org/10.3390/ijerph14070828

REIAD, N. A.; SALAM, O. E. A.; ABADIR, E. F.; HARRAZ, F. A. Adsorptive removal of iron and manganese ions from aqueous solutions with microporous chitosan/polyethylene glycol blend membrane. Journal of Environmental Sciences, v. 24, n. 8, p. 1425-1432, 2012. https://doi.org/10.1016/S1001-0742(11)60954-6

SALLEH, M. A. M.; MAHMOUD, D. K.; ABDUL KARIM, W. A. W.; IDRIS, A. Cationic and anionic dye adsorption by agricultural solid wastes: A comprehensive review. Desalination, v. 280, p. 1-13, 2011. http://doi.org/10.1016/j.desal.2011.07.019

SCHAFHAUSER, H. B.; GONÇALVES, R. T.; CONSOLIN, F. B. M.; ALMEIDA, C. V.; PINEDA, A. G. E.; CONSOLIN-FILHO, N. Estudo da adsorção de chumbo II em lignina modificada a partir do resíduo do milho. Revista Brasileira de Pesquisa em Alimentos, v. 6, p. 16-25, 2015. http://dx.doi.org/10.14685/rebrapa.v6i1.186

SHARMA, G.; THAKUR, B.; NAUSHAD, M.; AL-MUHTASEB, A. H.; KUMAR, A.; SILLANPAA, M.; MOLA, G. T. Fabrication and characterization of sodium dodecyl sulphate@ironsilicophosphate nanocomposite: Ion exchange properties and selectivity for binary metal ions. Materials Chemistry and Physics, v. 193, p. 129-139, 2017. http://dx.doi.org/10.1016/j.matchemphys.2017.02.010 
SUROVKA, D.; PERTILE, E. Sorption of Iron, Manganese, and Copper from Aqueous Solution Using Orange Peel: Optimization, Isothermic, Kinetic, and Thermodynamic Studies. Polish Journal of Environmental Studies, v. 26, n. 3, p. 795-800, 2017. https://doi.org/10.15244/pjoes/60499

TAVLIEVA, M. P.; GENIEVA, S. D.; GEORGIEVA, V. G.; VLAEV, L. T. Thermodynamics and kinetics of the removal of manganese (II) ions from aqueous solutions by white rice husk ash. Journal of Molecular Liquids, v. 211, p. 938-947, 2015. http://doi.org/10.1016/j.molliq.2015.08.015 